\title{
PENGARUH ONLINE PROMOTION TERHADAP REPURCHASE INTENTION DENGAN CONSUMER PERCEPTION SEBAGAI MEDIASI PADA TRAVEL ONLINE
}

\author{
Stefanie Adelia \\ Fakultas Ekonomi, Universitas Kristen Petra \\ E-mail: stefanieadelia97@gmail.com
}

\begin{abstract}
Abstrak: Strategi pemasaran seperti promosi via online adalah hal yang paling sering dilakukan di masa kini untuk menarik minat beli ulang konsumen ke layanan travel online dengan membuat persepsi konsumen yang baik. Media online dipilih sebagai media kampanye karena dapat meraih segmen pasar yang sangat luas dan tidak terbatas waktu dengan biaya yang relatif rendah dan dapat membentuk persepsi konsumen yang mempengaruhi minat beli konsumen. Riset pada pengaruh promosi online kepada minat beli ulang dengan persepsi konsumen sebagai mediasi pada travel online telah dilakukan kepada 100 orang pembeli travel online yang dipilih menggunakan non-probability sampling dengan teknik analisis data WarpPLS. Hasilnya menunjukkan bahwa promosi online memiliki efek positif pada minat beli ulang secara langsung dan minat beli ulang secara tidak langsung secara positif mempengaruhi melalui mediasi variabel persepsi konsumen. Studi ini membuktikan bahwa persepsi konsumen dapat menjadi mediasi yang baik antara promosi online dengan minat beli ulang.
\end{abstract}

Kata kunci: Promosi Online, Persepsi Konsumen, Minat Beli Ulang.

\begin{abstract}
Marketing strategies such as online promotion are now mostly done to attract customer repurchase intention to online travel services by establishing a good consumer perception. Online media is chosen as a media campaign because it is able to reach a very broad market segment and not limited to time with a relatively low cost and can form a consumer perception that affects the consumer's buying interest. Research on the influence of online promotion on repurchase intention with consumer perception as mediation on online travel is done to 100 online travel online buyers selected by nonprobability sampling with WarpPLS data analysis technique. The results showed that online promotion has a positive effect on repurchase intention directly and repurchase intention positively indirectly influence through the mediation variable consumer perception. This study proves that consumer perception can be a good mediation between online promotion and repurchase intention.
\end{abstract}

Keywords: Online Promotion, Consumer Perception, Repurchase Intention.

\section{PENDAHULUAN}

Usaha travel berkembang pesat di Indonesia ditandai dengan peningkatan keuntungan penjualan di situs travel online dari tahun ke tahun. Merujuk data e-Marketer, keuntungan penjualan situs travel online tahun ini mencapai \$5,97 miliar atau setara dengan Rp78 triliun pada tahun 2016. Angka ini naik dari tahun 2014 sebesar \$4,26 miliar dan tahun 2015 sebesar \$5 miliar. Diperkirakan pada tahun 2020 angkanya sudah mencapai $\$ 10,49$ miliar. Saat ini pesawat udara merupakan salah satu transportasi favorit untuk melakukan traveling, selain itu tren penggunaan kereta api meningkat dari tahun ke tahun. Dari rilis Pegipegi.com yang diterima Kompas Travel popularitas pemesanan tiket kereta api secara online terus meningkat tiap tahunnya.

Untuk travel tradisional atau konvensional saat ini sudah mengalami peralihan ke travel online. Namun pengguna Online Travel Agent (OTA) di Indonesia masih sangat kecil sekitar 12 persen apabila dibandingkan dengan negara Inggris yang sudah mencapai 78 persen. Travel online ini sendiri menggunakan web sebagai media untuk berkomunikasi dengan para pelanggan. Dengan jumlah pengguna internet yang mencapai angka 82 juta orang atau sekitar 30\% dari jumlah penduduk Indonesia, merupakan tambang emas bagi travel online dalam menggunakan web communication untuk memanfaatkan potensi keuntungan yang dapat diraih. Pertumbuhan ini didukung dengan data dari Menkominfo yang menyebutkan bahwa nilai transaksi e-commerce pada tahun 2013 mencapai angka 130 triliun rupiah. Ini merupakan angka yang fantastis mengingat hanya sekitar 7\% pengguna internet di Indonesia yang pernah belanja secara online.

Promosi merupakan kegiatan pemasaran yang memiliki dampak sangat besar terhadap minat beli kembali konsumen terhadap produk yang ditawarkan. Melalui survei yang dilakukan, konsumen banyak melakukan pembelian karena termotivasi oleh kegiatan promosi yang dilakukan. Menurut Chung dan Lee (2003) promosi memiliki mempunyai pengaruh positif terhadap minat beli kembali konsumen. Strategi kupon dan harga promosi merupakan strategi yang dapat meningkatkan minat beli kembali konsumen. 
Selain itu menurut Moslehi dan Haeri (2016) promosi harga memiliki hubungan yang mempengaruhi minat beli kembali.

Dalam travel online, melalui kegiatan promosi dapat mempengaruhi persepsi, emosi, pengalaman konsumen seperti pola dalam melakukan pembelian (Mahmood \& Khan, 2014). Promosi sendiri dapat dilakukan melalui media TV, website, majalah, dan lain sebagainya untuk dapat memberikan persepsi kepada konsumen yang ingin dituju. Dalam layanan pemasaran, media komunikasi yang dipakai sangat berperan penting karena berpengaruh untuk membentuk image yang kuat dan kredibilitas, kepercayaan dan keyakinan konsumen (Lovelock dan Gummesson, 2004). Dapat dilihat dari beberapa travel online seperti Traveloka, tiket.com, dan Pegipegi yang sering melakukan promosi di website sehingga semakin dikenal dan dipercaya oleh pengguna travel online Indonesia. Hasil survei konsumen menunjukan bahwa persepsi konsumen tentang promosi penjualan memiliki hubungan positif yang signifikan (Rizvi\& Nazihs, 2011).

Persepsi yang baik akan memberikan daya tarik lebih kepada konsumen sehingga menimbulkan niat beli kembali kepada produk maupun jasa yang ditawarkan travel online. Menurut Zhang (2011) minat beli kembali dipengaruhi persepsi yang dimiliki oleh konsumen. Persepsi konsumen tentang keamanan akan menimbulkan kepercayaan yang memberi dampak positif kepada minat beli kembali (Safa \& Solms, 2016).

Berdasarkan latar belakang permasalahan di atas, maka rumusan masalah penelitian ini adalah sebagai berikut:

1. Apakah online promotion berpengaruh pada customer perception travel online?

2. Apakah online promotion berpengaruh terhadap repurchase intention travel online?

3. Apakah consumer perception travel online berpengaruh terhadap repurchase intention?

\section{TINJAUAN PUSTAKA}

\section{Online Promotion}

Promosi merupakan salah satu faktor penentu keberhasilan suatu program pemasaran. Betapapun berkualitasnya suatu produk, bila konsumen belum pernah mendengarnya dan tidak yakin bahwa produk itu akan berguna bagi mereka, maka mereka tidak akan pernah membelinya. Pada hakikatnya promosi adalah suatu bentuk komunikasi pemasaran. Yang dimaksud dengan komunikasi pemasaran adalah aktivitas pemasaran yang berusaha menyebarkan informasi, mempengaruhi, atau mengingatkan pasar sasaran dan produknya agar bersedia menerima, membeli, loyal pada produk yang ditawarkan perusahaan yang bersangkutan. Internet telah meningkatkan bauran promosi dan menekan banyak biaya promosi. Online Promotion menjadi salah satu cara untuk menarik konsumen baru dikarenakan kemudahan yang ditawarkan kepada konsumen untuk mengakses internet. Konsumen diundang ke website jika ingin lebih tahu tentang produk atau jasa yang ditawarkan (Abou-Moghli dan Al-Abdallah,2012).

Berikut adalah komposisi strategi promosi, yaitu:

\section{A. Iklan}

Iklan dianggap untuk membantu pembeli untuk belajar dan mengingat merek dan manfaatnya dengan mengulangi asosiasi pesan dan bangunan antara merek, logo, gambar, dan manfaat bentuk pengkondisian klasik (Smith, 1998). Iklan melalui internet memungkinkan pengiklan untuk menargetkan komunikasi kepada pembeli yang spesifik dengan lebih fokus daripada menggunakan variabel lainnya (Cravens \& Piercy, 2013).

\section{B. Personal Selling}

Personal selling dapat didefinisikan sebagai komunikasi informasi secara pribadi yang mempengaruhi calon pelanggan untuk membeli sesuatu baik layanan, ide, atau sesuatu yang lain (Futrell, 1992). Hal ini diciptakan oleh Marks (1997) untuk menjadi face to face. Personal selling terdiri dari komunikasi verbal antara penjual atau tim penjualan dan satu atau lebih calon pembeli dengan tujuan membuat atau mempengaruhi penjualan (Cravens \& Piercy, 2013).

\section{Promosi Penjualan}

Promosi penjualan adalah berbagai teknik pemasaran taktis yang dirancang dalam kerangka pemasaran strategis untuk menambah nilai suatu produk atau jasa untuk mencapai tujuan penjualan dan pemasaran tertentu. Hal ini termasuk seperti pameran, kupon, pameran dagang, premi, dan hadiah, sampel, pembiayaan bunga rendah (Kotler \& Keller, 2009).

\section{Direct Marketing}

Pemasaran langsung mencakup berbagai saluran komunikasi yang memungkinkan perusahaan untuk melakukan kontak langsung dengan pembeli individu. Contohnya dapat seperti catalog, direct mail, telemarketing, television selling, radio/majalah/koran, dan electronic shopping. Fitur yang membedakan dari pemasaran langsung adalah kesempatan bagi pemasar 
untuk mendapatkan akses secara langsung ke pembeli.

\section{E. Internet Marketing}

Pemasaran internet mencakup penggunaan sebuah website perusahaan dalam hubungannya dengan teknik promosi online seperti mesin pencari, iklan banner, e-mail langsung dan link atau jasa dari dari situs web lainnya untuk mendapatkan pelanggan baru dan meningkatkan layanan kepada pelanggan yang sudah ada sehingga membantu mengembangkan hubungan (Chaffey et al., 2003). Pemasaran internet membantu memprediksi perilaku pelanggan yang membuat perusahaan lebih mudah untuk menjaga hubungan baik dengan pelanggan (Nematbakhsh, 2007).

\section{F. Public Relation}

Public relation dapat digambarkan sebagai fungsi operasional yang bertujuan pada komunikasi yang lebih dan benar memiliki efek timbal balik antara perusahaan, organisasi, dan kelompok masyarakat yang mereka kembangkan dan mempertahankan hubungan yang sudah ada (David, 2001). Public relation adalah praktek mengelola aliran informasi antara organisasi dengan publik (Grunig et al., 1994).

\section{Consumer Perception}

Persepsi konsumen didefinisikan sebagai proses yang dilakukan individu untuk memilih, mengatur, dan menafsirkan stimuli ke dalam gambar yang berarti dan masuk akal mengenai dunia (Kotler \& Keller, 2009, p. 203). Dua individu mungkin menerima stimuli yang sama dalam kondisi nyata yang sama, tetapi bagaimana setiap orang mengenal, memilih, mengatur dan menafsirkannya merupakan proses yang sangat individual berdasarkan kebutuhan, nilai-nilai, dan harapan setiap orang itu sendiri. Pengaruh yang diberikan setiap variabel ini terhadap proses memperoleh persepsi.

\section{Konsep Perceived Value}

Ketika dalam studi eksplorasi yang membahas tentang nilai, menggunakan istilah dalam berbagai sudut pandang, menggambarkan berbagai atribut dan tingkat abstraksi tinggi yang lebih tinggi sehingga memberikan nilai kepada konsumen. Pola konsumen dari studi eksplorasi dapat dikelompokan menjadi empat, yaitu (Schiffman, \& Kanuk, 2008):

a) Value is low price

b) Value is whatever I want in a product c) Value is the quality I get for the price I pay

d) Value is what I get for what I give

\section{Repurchase Intention}

Repurchase intention adalah status konsumen yang membeli setidaknya sekali dari pusat perbelanjaan dan memiliki keinginan untuk membeli lagi. Niat pembeli untuk membeli kembali merupakan faktor yang sangat diperlukan untuk keberhasilan operasi pembeliaan di internet. Pelanggan setia berpengaruh langsung terhadap keberhasilan suatu perusahaan yang ditentukan oleh niat pelanggan membeli kembali (Chung \& Lee, 2003). Minat beli konsumen memliki dua dimensi sebagai berikut (Zhou \& Wang, 2009, Kim, Galliers, Shin, \& Ryoo, 2012):

1. Web Design Quality

Interaktivitas online adalah cara yang berharga untuk memperbaiki kualitas situs web bisnis dan perancang web harus mengerti bagaimana desain mempengaruhi kualitas web dan citra organisasi pada konsumen (Levis, Helfert, \& Brady, 2008).

2. Satisfaction

Dengan meningkatkan kepuasan pelanggan akan sangat mudah untuk meningkatkan konsumen berkunjung kembali, melakukan pembeliaan ulang, dan merekomendasikan produk kepada orang lain (To, Liao, \& Lin, 2007).

\section{Kerangka Hipotesis}

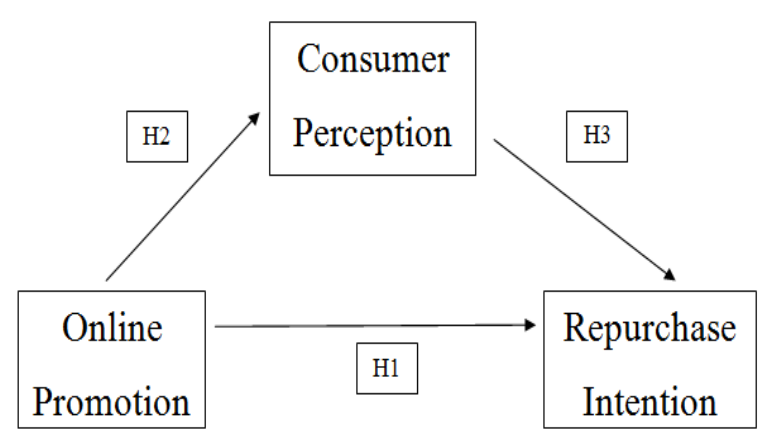

Gambar 1. Kerangka Hipotesis

\section{Hipotesis}

Adapun hipotesis yang diajukan pada penelitian ini adalah:

H1: Online promotion berpengaruh terhadap repurchase intention pelanggan travel online.

H2: Online promotion berpengaruh terhadap consumer perception pelanggan travel online.

H3: Consumer perception berpengaruh terhadap repurchase intention pelanggan travel online. 


\section{METODE PENELITIAN}

\section{Populasi dan Sampel}

Dalam penelitian kuantitatif populasi diartikan sebagai wilayah generalisasi yang terdiri atas: obyek/ subyek yang mempunyai kualitas dan karakteristik tertentu yang ditetapkan oleh peneliti untuk dipelajari dan kemudian ditarik kesimpulannya. Populasi dari penelitian ini adalah semua orang yang memiliki kemampuan untuk menggunakan komputer dan sudah pernah melihat iklan dari travel online melalui website. Sedangkan sampel adalah bagian dari jumlah dan karakteristik yang dimiliki oleh populasi tersebut. Bila populasi besar dan peniliti tidak mungkin mempelajari semua yang ada pada populasi, misalnya karena keterbatasan dana, tenaga, dan waktu, maka sampel yang diambil dari populasi harus betul-betul representative atau mewakili.

Teknik sampling adalah teknik pengambilan sampel. Pengambilan sampel yang akan digunakan dalam penelitian memiliki beberapa teknik sampling. Dalam penelitian ini akan menggunakan teknik nonprobrability sampling. Menurut Sugiyono (2010) menyatakan bahwa non-probrability sampling adalah teknik pengambilan sampel yang tidak memberi peluang atau kesempatan sama bagi setiap unsur atau anggota populasi untuk dipilih menjadi sampel. Nonprobrability sampling memiliki berebagai macam jenis, diantaranya adalah sampling sistemastis, kuota, aksidental, purposive, jenuh, dan snowball. Sedangkan dalam penelitian ini akan menggunakan purposive sampling atau juga bisa disebut judgement sampling.

\section{Definisi Operasional Variabel}

Definisi operasional variabel yang digunakan dalam penelitian ini terdiri dari 3 variabel, yaitu:

- Variabel eksogen/independen, yaitu Online Promotion (X1) dengan dimensi:

1. Iklan adalah alat untuk membantu mengingatkan, memberi informasi dan menyadarkan konsumen terhadap produk yang ditawarkan.

2. Promosi merupakan metode yang dipakai perusahaan untuk menarik minat beli kembali konsumen.

3. Internet Marketing menggunakan media online dan memiliki hubungan dengan teknik promosi online seperti mesin pencari, iklan banner, e-mail langsung dan link atau jasa dari dari situs web lainnya untuk mendapatkan pelanggan.

- Variabel Mediasi yaitu, Consumer Perception $\left(\mathrm{Y}_{2}\right)$ dengan dimensi, sebagai berikut:
1. Perceived Value merupakan persepsi nilai yang diberikan kepada konsumen dengan dasar sesuai keinginan dan pikiran konsumen itu sendiri.

- Variabel Endogen $\left(\mathrm{Y}_{1}\right)$ yaitu Repurchase Intention, dengan dimensi:

1. Satisfaction adalah kepuasan konsumen terhadap suatu produk yang ditawarkan oleh perusahaan.

2. Web Design Quality adalah merupakan cara yang dapat mempengaruhi konsumen terhadap citra produk dan kualitas dari perusahaan.

\section{Teknik Analisis Data}

Pemilihan teknik analisa statistika adalah bagian penting untuk megnuji hipotesis salah satu alat analisis yang banyak digunakan adalah SEM (structural equation marketing). Penelitian ini menggunakan pendekatan WarpPLS yang merupakan pengembangan dari analisis PLS (partial least square), model ini dikembangkan sebagai alternative untuk situasi dimana dasar teori pada perancangan model lemah atau indikator yang tersedia tidak memenuhi model pengukuran reflesif.

\section{HASIL PENELITIAN DAN PEMBAHASAN}

\section{Path Analysis WarpPLS 5.0}

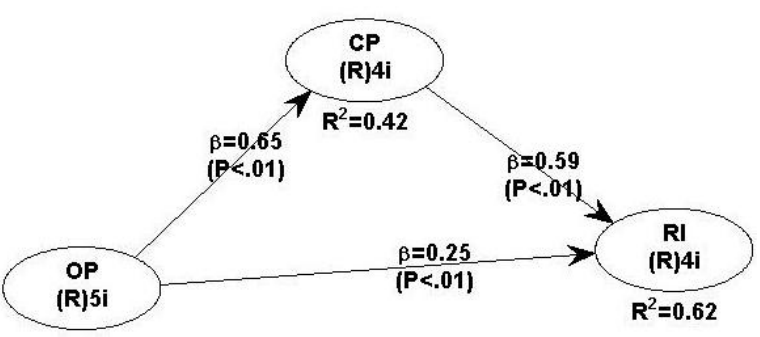

Gambar 2. Path Analysis

Gambar diatas merupakan hasil dari pengujian untuk model direct effect. Hasil diatas menunjukan bahwa pengaruh langsung Online Promotion $\left(\mathrm{X}_{1}\right)$ terhadap Repurchase Intention $\left(\mathrm{Y}_{1}\right)$ adalah signifikan $(\mathrm{p}<0,01)$ dengan koefisiensi jalur sebesar 0,25 . Untuk Online Promotion $\left(\mathrm{X}_{1}\right)$ terhadap Consumer Perception $\left(\mathrm{Y}_{2}\right)$ adalah signifikan $(\mathrm{p}<0,01)$ dengan koefisien jalur sebesar 0,65. Kemudian variabel Consumer Perception $\left(\mathrm{Y}_{2}\right)$ terhadap Repurchase Intention $\left(\mathrm{Y}_{1}\right)$ adalah signifikan $(\mathrm{p}<0,01)$ dengan koefisien 0,59 .

Jumlah koefisien jalur $=0.25+0.65 \times 0.59$

$$
\begin{aligned}
& =0.25+0.383 \\
& =0.63
\end{aligned}
$$




\section{Composite Reliability}

Tabel 1. Composite Reliability

\begin{tabular}{|l|r|l|r|l|}
\hline Variabel & $\begin{array}{c}\text { Composite } \\
\text { Reliability }\end{array}$ & Keterangan & \multicolumn{1}{c|}{$\begin{array}{c}\text { Cronbach's } \\
\text { Alpha }\end{array}$} & Keterangan \\
\hline $\mathrm{OP}(\mathrm{X} 1)$ & 0.793 & Memenuhi & 0.674 & Reliabel \\
\hline $\mathrm{RI}(\mathrm{Y} 1)$ & 0.931 & Memenuhi & 0.901 & Reliabel \\
\hline $\mathrm{CP}(\mathrm{Y} 2)$ & 0.920 & Memenuhi & 0.884 & Reliabel \\
\hline
\end{tabular}

Nilai composite reliability dan nilai cronbach's alpha digunakan untuk mengetahui reliabilitas instrumen penelitian. Berdasarkan output di atas, dapat diketahui bahwa composite reliability $>0,70$ untuk semua variabel. Sehingga dapat dinyatakan semua variabel dalam penelitian yang dilakukan telah memenuhi syarat dari reliabilitas. Sedangkan untuk cronbach's alpha didapati nilai untuk variabel OP $\left(\mathrm{X}_{1}\right)$ 0,674 yang berarti cukup reliabel, $\mathrm{RI}\left(\mathrm{Y}_{1}\right)$ 0,901 yang berarti sangat reliabel, dan $\mathrm{CP}\left(\mathrm{Y}_{2}\right)$ 0,884 yang berarti cukup reliabel.

\section{Discriminant Validity}

Tabel 2. Discriminant Validity

\begin{tabular}{cccc}
\hline & OP & RI & CP \\
\hline OP & $(0,662)$ & 0,637 & 0,622 \\
RI & 0,637 & $(0,878)$ & 0,754 \\
CP & 0,622 & 0,754 & $(0,862)$ \\
\hline
\end{tabular}

Output Correlations among latent variables merupakan koefisien korelasi antar variabel dengan disertai $p$-value. Output tersebut penting untuk evaluasi validitas diskriminan instrumen penelitian. Kriteria yang digunakan adalah akar kuadrat (square roots) average variance extracted (AVE) yaitu nilai kolom diagonal dan diberi tanda kurung harus lebih tinggi dari korelasi antar variabel laten pada kolom yang sama (di atas atau di bawahnya) maka dapat dikatakan memiliki discriminant validity yang baik. Direkomendasikan nilai pengukuran $>0,50$ dan dipandang valid.

Berdasarkan output tersebut dapat diketahui bahwa validitas diskriminan untuk variabel $\mathrm{OP}\left(\mathrm{X}_{1}\right)$ 0,662 sudah memenuhi karena akar AVE lebih besar daripada $\mathrm{RI}\left(\mathrm{Y}_{1}\right)$ 0,637 dan $\mathrm{CP}\left(\mathrm{Y}_{2}\right)$ 0,622, sehingga dapat dikatakan variabel OP $\left(\mathrm{X}_{1}\right)$ memenuhi kriteria validitas diskriminan. Untuk variabel $\mathrm{RI}\left(\mathrm{Y}_{1}\right)$ 0,878 telah memenuhi kriteria akar AVE sebesar karena lebih besar daripada 0,637 dan 0,754. Sedangkan variabel $\mathrm{CP}\left(\mathrm{Y}_{2}\right)$ telah memenuhi syarat validitas karena akar AVE sebesar 0,862 yang lebih besar dari 0,622 dan 0,754 .

\section{Cross Loading Factor}

Pada tabel dibawah ini validitas cross loading factor sudah memenuhi syarat sehingga sudah dapat menggambarkan indikator dari variabel.

Tabel 3. Cross Loading Factor Online Promotion

\begin{tabular}{|l|r|r|}
\hline OP & \multicolumn{1}{|c|}{ RI } & \multicolumn{1}{|c|}{ CP } \\
\hline 0.486 & -0.269 & -0.156 \\
\hline 0.674 & -0.379 & 0.046 \\
\hline 0.692 & -0.201 & -0.066 \\
\hline 0.750 & 0.499 & -0.221 \\
\hline 0.680 & 0.220 & 0.376 \\
\hline
\end{tabular}

Cross loading dari indikator online promotion terlihat lebih besar dari indikator variabel lainnya. Dengan hasil data diatas menggambarkan bahwa indikator dari variabel online promotion sudah dapat menggambarkan variabel online promotion dibandingkan dengan variabel lainnya.

Tabel 4. Cross Loading Factor Repurchase Intention

\begin{tabular}{|r|r|r|}
\hline \multicolumn{1}{|l|}{ OP } & \multicolumn{1}{|l|}{ RI } & \multicolumn{1}{c|}{ CP } \\
\hline 0.023 & 0.905 & 0.183 \\
\hline-0.051 & 0.873 & 0.007 \\
\hline 0.116 & 0.855 & -0.235 \\
\hline-0.084 & 0.880 & 0.033 \\
\hline
\end{tabular}

Cross loading dari indikator Repurchase Intention terlihat lebih besar dari indikator variabel lainnya. Dengan hasil data diatas menggambarkan bahwa indikator dari variabel repurchase intention sudah dapat menggambarkan variabel repurchase intention dibandingkan dengan variabel lainnya.

Tabel 5. Cross Loading Factor Consumer Perception

\begin{tabular}{|r|r|r|}
\hline \multicolumn{1}{|l|}{ OP } & \multicolumn{1}{|l|}{ RI } & \multicolumn{1}{l|}{ CP } \\
\hline-0.002 & -0.212 & 0.798 \\
\hline-0.101 & 0.082 & 0.870 \\
\hline 0.060 & -0.016 & 0.885 \\
\hline 0.040 & 0.126 & 0.893 \\
\hline
\end{tabular}

Cross loading dari indikator Consumer Perception terlihat lebih besar dari indikator variabel lainnya. Dengan hasil data diatas menggambarkan bahwa indikator dari variabel consumer perception sudah dapat menggambarkan variabel consumer perception dibandingkan dengan variabel lainnya.

\section{Uji Hipotesis}

Tabel 6. Kesimpulan Hipotesis

\begin{tabular}{|l|l|l|r|l|}
\hline Hipotesis & Jalur & $\boldsymbol{\beta}$ & $\boldsymbol{p}$-value & Keterangan \\
\hline $\mathrm{H}_{1}$ & OP (X) ke RI (Y1) & 0,25 & $<0,01$ & Signifikan \\
\hline $\mathrm{H}_{2}$ & OP (X) ke CP (Y2) & 0,65 & $<0,01$ & Signifikan \\
\hline $\mathrm{H}_{3}$ & CP (Y2) ke RI (Y1) & 0,59 & $<0,01$ & Signifikan \\
\hline
\end{tabular}


- Hipotesis variabel $\mathrm{X}_{1}$ (Online Perception) dengan $\mathrm{Y}_{1}$ (Repurchase Intention)

$\mathrm{H} 1$ : Terdapat pengaruh online promotion $\left(\mathrm{X}_{1}\right)$ terhadap repurchase intentions $\left(\mathrm{Y}_{1}\right)$ pada konsumen travel online.

Temuan: Terima $\mathbf{H}_{\mathbf{1}}$

Berdasarkan hasil perhitungan seperti yang tercantum pada tabel 4.19, koefisien jalur dari OP $\left(\mathrm{X}_{1}\right)$ ke $\mathrm{RI}\left(\mathrm{Y}_{1}\right)>0,100(\beta=0,25)$ dengan nilai $\mathrm{p}<$ $0,05$ (p-value $<0,01)$.

- Hipotesis variabel $X_{1}$ (Online Promotion) dengan $\mathrm{Y}_{2}$ (consumer perception)

$\mathrm{H} 2$ : Terdapat pengaruh online promotion $\left(\mathrm{X}_{1}\right)$ terhadap consumer perception $\left(\mathrm{Y}_{2}\right)$ pada konsumen travel online.

Temuan: Terima $\mathbf{H}_{2}$

Berdasarkan hasil perhitungan seperti yang tercantum pada tabel 4.14, koefisien jalur dari OP $\left(\mathrm{X}_{1}\right)$ ke $\mathrm{CP}\left(\mathrm{Y}_{2}\right)>0,100(\beta=0,65)$ dengan nilai $\mathrm{p}$ $<0,05$ ( $p$-value $<0,01)$.

- Hipotesis variabel $\mathrm{Y}_{2}$ (Consumer Perception) dengan $Y_{1}$ ( Repurchase Intention)

- $\mathrm{H}_{3}$ : Terdapat pengaruh consumer perception terhadap repurchase intention pada konsumen travel online.

Temuan : Terima $\mathbf{H 3}$

Berdasarkan hasil perhitungan seperti yang tercantum pada tabel 4.14, koefisien jalur dari $\mathrm{CP}$ $\left(\mathrm{Y}_{2}\right)$ ke RI $\left(\mathrm{Y}_{1}\right)>0,100(\beta=0,59)$ dengan nilai $\mathrm{p}<$ $0,05$ ( $p$-value $<0,01)$.

\section{KESIMPULAN DAN SARAN}

\section{Kesimpulan}

Berdasarkan hasil penelitian yang dilakukan mengenai online promotion terhadap repurchase intention dengan consumer perception sebegai mediasi, pada konsumen yang pernah menggunakan travel online diperoleh kesimpulan bahwa Online Promotion yang dilakukan oleh travel online dengan cara beriklan dan promosi penjualan akan dapat membangun Consumer Perception dalam hal efisien waktu, tenaga, serta biaya. Sehingga dapat disimpulkan bahwa Online Promotion dan Consumer Perception menjadi variabel yang sangat penting dalam membentuk Repurchase Intention travel online.

\section{Saran}

Travel online harus mempertahankan kerjasama dengan media online lainya baik seperti Facebook, Twitter, dan lain sebagainya yang sejenis. Namun travel online harus selalu memberikan inovasi kemudahan lain sehingga orang dapat selalu terhubung travel online dengan mudah melalui media online selain website resmi dari travel online sendiri.

Travel online perlu mempertahankan iklan dan promosi penjualan berupa potongan harga sehingga konsumen selalu menggunakan travel online ketika ingin membeli tiket atau memesan kamar hotel. Hal ini sangat untuk mempertahankan minat pembeliaan kembali dan persepsi konsumen pada travel online.

Travel online perlu untuk mempertahankan pelayanan terhadap konsumen sehingga persepsi konsumen akan efisiensi biaya, waktu, dan tenaga dapat selalu terjaga. Hal ini akan memberikan kepuasan kepada pelanggan dalam menggunakan travel online

\section{DAFTAR PUSTAKA}

Al-Abdallah, G., \& Abou-Moghli, A. 2012. the Effect of Promotional Mix on Internet Adoption in Jordanian Small and Medium Enterprises. European Scientific Journal, 8(12), 96-112. Retrieved from http://eujournal.org/index.php/esj/ article/view/182

Chaffey, D., R. Mayer, K. Johnston, \& Ellis-Chadwich, F. 2003. Internet Marketing, Strategy, Implementation and Practice. Harlow, UK: Prentice Hall. London.

Chung, I., \& Lee, M. 2003. A Study of Influencing Factors for Repurchase Intention in Internet Shopping Malls, $0(\mathrm{C})$.

Cravens, David. W., dan Piercy, Nigel. F. 2013, Strategic Marketing 10th Edition. New York: McGraw-Hill International Edition.

David, Phillips. 2001. Online Public Relations. Institute of Public Relations London (Great Britain): Kogan Page Ltd.

Futrell, C. 1992. Personal selling: How to succeed in sales. Burr Ridge, IL.: Irwin.

Grunig, James E. and Todd Hunt. 1994. Managing Public Relations. Orlando, FL: Harcourt Brace Jovanovich, sixth Edition.

Khan, S. M., \& Mahmood, R. 2014. Impact of Service Marketing Mixes on Customer Perception: A Study on Eastern Bank Limited, Bangladesh. European Journal of Business and Management Online), 6(34), pp. 2222-2839.

Kim, C., Galliers, R.D., Shin, N. \& Ryoo, J.H. 2012. Factors influencing Internet shopping value and customer repurchase intention. Electronic Commerce Research and Applications, 11(4), pp. 374-387.

Kotler, P., \& Keller, K. L. 2009. Marketing Management (13th ed.). Upper Saddle River, New Jersey: Pearson Prentice-Hall. 
Levis, M., Helfert, M., Brady, M., Levis, M., Helfert, M., \& Brady, M. 2008. Website Design Quality and Form Input Validation: An Empirical Study on Irish Corporate Websites, (June), 91-100.

Lovelock, C. \& Gummesson, E. 2004. Whither services marketing? In search of a new paradigm and fresh perspectives. Journal of Services Research, 7(1), pp. 20-41.

Marks, R.B. 1997. Personal Selling: A Relationship Approach. New Jersey: Prentice Hall.

Moslehi, H., \& Haeri, F. A. 2016. Effects of Promotion on Perceived Quality and Repurchase Intention, 4(12), pp. 457-461.

Naresh K. Malhotra 2009. Riset Pemasaran: Pendekatan terapan, jilid 1. PT Indeks

Nazish, S., \& Rizvi, Z. 2011. Impact of Sales Promotion on Organizations' Profitability and Consumer's Perception in Pakistan. Interdisciplinary Journal Of Contemporary Research In Business, 3(5), 296-310.

Nematbakhsh M.A., M. Solgi. 2007. Personalization Model for e-Marketing. IMECS 1, 845-849.
Safa, N. S., Mandela, N., Africa, S., Safa, N., \& Solms, V. 2016. Customers repurchase intention formation in,1-9.https://doi.org/10.4102/sajim.v18i1.712

Schiffman, L., \& Kanuk, L. L. 2008. Perilaku Konsumen (7th ed.). Jakarta: PT. Indeks.

Smith P.R. 1998. Marketing Communication an Integrated Approach. Bell and Bain Ltd. London.

Sugiyono. (2010). Metode Penelitian Bisnis: Pendekatan Kuantitatif, Kualitatif, dan R\&D. Bandung: Alfabeta.

To, P., Liao, C., and Lin, T. Shopping motivations on Internet: a study based on utilitarian and hedonic value. Technovation, 27(12), 2007, pp. 774-784.

Zhou, T., Lu, Y., \& Wang, B. 2009. The relative importance of website design quality and service quality in determining consumers' online repurchase behavior. Information Systems Management, 26(4), pp. 327-337.

Zhang, Yixiang, Fang, Yulin, Wei, Kee Kwok. Ramsey, Elaine. McCole, Patrick. Chen, Huaping, 2011. Repurchase Intention in B2C ecommerce - A relationship quality Perspective. Information \& Management, 48, pp. 192-200. 